\title{
サービス創出基盤としての NGN
}

NGN as a Service Creation Platform

\author{
荒木靖宏 ${ }^{\dagger 1, \dagger 2}$ Yasuhiro Araki ${ }^{\dagger 1, \dagger 2}$ 森川博之 ${ }^{\dagger 1}$ Hiroyuki Morikawa $^{\dagger 1}$
}

Summary $=\quad \begin{aligned} & \text { NGN (Next Generation Network) / IMS (IP Multimedia Subsystem) は，ユーザ } \\ & \text { 情報管理機能やネットワーク制御機能など，今まで通信事業者内に閉じた門外 }\end{aligned}$ 不出の機能をサードパーティ事業者に公開するインタフェースを定義している. 多くのサードパーティ事業者の参画 を促すことで，NGN/IMS の機能を利用した革新的なアプリケーションの創出が期待されている．しかしながら，IMS はインタフェースが規定されているのみで，アプリケーション構築に資する機能まで規定されていない. SDP (Service Delivery Platform）は，NGN/IMS が具備する機能とアプリケーションとを仲介するオープンなアプリケーション開発環 境であり，SDPを用いることでアプリケーション開発速度の向上やコスト低減を図ることができる. 本論文では，IMS におけるサービス提供形態や NGN/IMS 上でのアプリケーションを示すことで，NGN/IMS が具備する機能を明らかに する. 次に，SDPが提供する機能や構成例を示し，多彩な NGN/IMS アプリケーションの創出に向けて SDPが果たす べき役割を明らかにする.

\section{Key words $=$ 次世代ネットワーク，NGN， IMS，SDP}

\section{1.まえがき}

国際電気通信連合電気通信標準化部門 ITU-T（International Telecommunication Union Telecommunication Standardization Sector）では, NGN の提供機能を, IP パケット転送を行うトランスポートストラタムと，それ を制御するサービスストラタムとの二つの層に分離して いる [1].

また，NGN が提供するサービスを「インターネット アクセス」「PSTN (Public Switched Telephone Network, 公衆電話交換網) エミュレーション」「ISDNエミュレー ション」「公衆サービス」「マルチメディアサービス」「そ の他の付加価値サービス」の六つに分類している.

NGN が提供するこれらのサービスのうち，「マルチメ ディアサービス」と「その他の付加価値サービス」の二つ がNGN ならではのサービスであり，これら二つのサー ビスをサービスストラタムで実現するための構成要素が IMS である [2].

$\dagger 1$ 東京大学, 東京都

The University of Tokyo, Tokyo,153-8904 Japan

$\dagger 2$ 現, (株) ディー・エヌ・エー, 東京都

DNA Co. Ltd., Tokyo, 151-0053 Japan
IMS の特徵は，ユーザの位置情報やプレゼンス情報な どを管理するユーザ情報管理機能と, QoS 制御やメディ アストリーム制御などのネットワーク制御機能とを有して いることである.これらの IMS 特有の機能を利用するこ とで,アプリケーション開発者は多彩なアプリケーション を構築できる. 例えば, ユーザの位置情報に基づいて近隣 のディジタルサイネージ端末に広告配信を行うサービス や，ユーザが所有するパーソナルコンピュータ (PC), 携 帯電話, IPTV 機器などの複数のデバイスをグループ化し てネットワーク接続環境に応じてストリーミングメデイア の配信先を切り換えるサービスなどが実現できる.

ユーザ情報管理機能やネットワーク制御機能などの 機能は, 今まで通信事業者内に閉じた門外不出の機能で あった。すなわち, 通信事業者ではないサードパーティ 事業者が新たなアプリケーションの開発を試みようにも, これらの機能にアクセスすることができなかった。これ に対して, IMS では，これらの機能にアクセスするため のインタフェースが定義されている.アプリケーション の構築に多くのサードパーティ事業者の参画を促すこと ができれば，多彩なアプリケーションの創出が期待でき る. IMS の機能を用いることで, 現在のインターネット 上では実現できない革新的なアプリケーションが花開く 
可能性もある.

このような期待の中で核となるのが SDP（サービス 提供基盤) である. SDP はオープンなアプリケーション 開発環境であり，ネットワークが具備する機能とアプリ ケーションとを仲介するものである. SDP を利用するこ とで，アプリケーション開発者は SIP (Session Initiation Protocol）などの通信制御プロトコルの詳細を知ることな く，上位のアプリケーションの開発に専念することがで きる。また，ユーザ管理，課金，認証などのように，ア プリケーション間で共用することが可能な機能をプラッ トホームとして整備することで，アプリケーションの開 発負荷を低減できる。このような開発環境を準備するこ とで，アプリケーション開発速度の向上やコスト低減と ともに，多くのサードパーティ事業者の参画を促して多 様なアプリケーションが創出されることが期待される.

SDP の登場により，通信事業者の事業モデルが一変す る可能性もある。通信事業者はネットワーク機能を外部 に提供することにより，回線使用料徴収モデルから機能 使用量徴収モデルへと転換を図り，プラットホームビジ ネスを実現できるためである，i-mode を例に出すまでも なく，多くのサードパーティ事業者を巻き込み，多彩な アプリケーションをSDP 上で提供できる通信事業者が覇
者となる世界である。

本論文では，まず2.で IMS でのサービス提供形態につ いて述へ，IMS の基本構成要素である CSCF（Call Session Control Function) や HSS (Home Subscriber Service) の機 能を示す. 次に， 3. において IMS 上での基本アプリケー ションを示すことで, IMS が具備する機能を用いて様々 なアプリケーションが実現できることを示す．最後に， 4. では SDP の機能や構成例について述べ，多彩なアプリ ケーションの創出に向けて SDP が果たすべき役割を明ら かにする。

\section{IMS におけるサービス提供形態}

図 1 に，ユーザが IMS 上のアプリケーションを利用す るまでの流れを示す。図 1 は, ユーザがポータルページ のメニュー画面にアクセスし，所望のアプリケーション (アプリケーション 1 (会議)）を選択することで, 当該ア プリケーションを利用する手順を示した図である。

アプリケーション利用までの手順は, (1) S-CSCF への 端末の登録，（2）アプリケーションの利用登録，（3）ア プリケーションを利用するためのセッション確立という

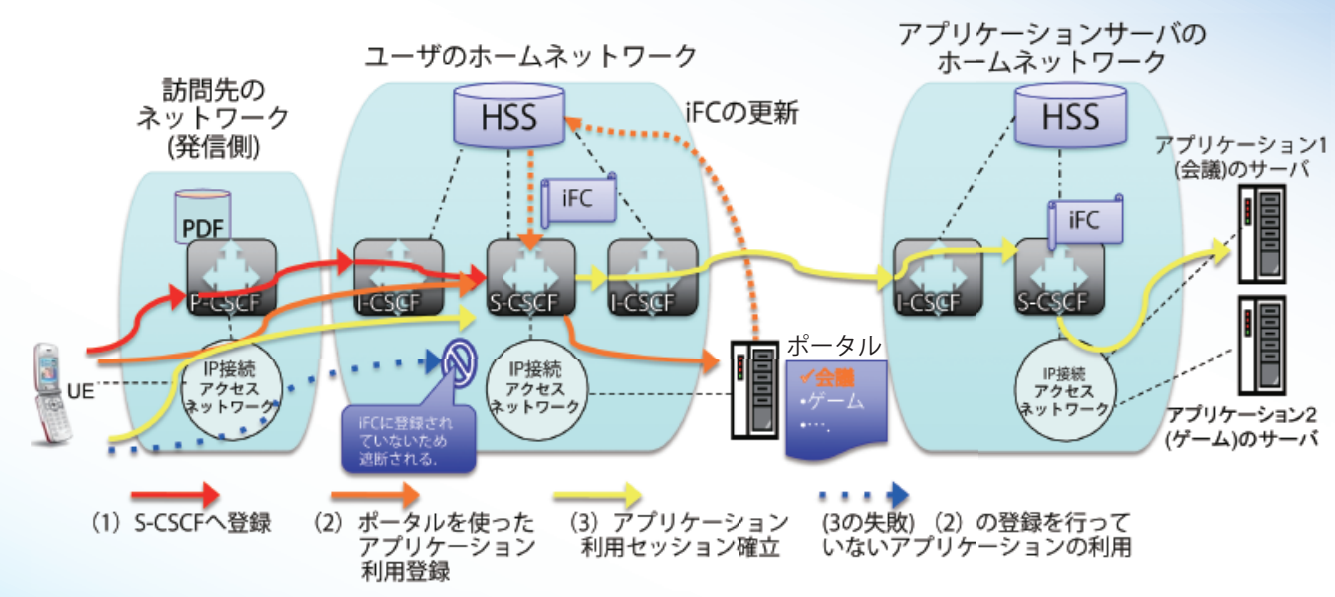

ユーザのホームネットワーク：ユーザが通常利用するネットワークのこと. 加入者情報はこのネットワークが管理している. 訪問先のネットワーク：例えば外国旅行時などのように，ローミングして使用するネットワーク.

\section{CSCF (呼セッション制御機能)の役割}

CSCF は役割に応じて，S-CSCF，P-CSCF， I-CSCF が規定されている。

S-CSCF : Serving-Call Session Control Function ；セッション状態を管理する SIPサーバ. SIPメッセージをユーザのサービス プロファイル内の iFC に従ってアプリケーションサーバやユーザへ転送する.

P-CSCF : Proxy-Call Session Control Function ; 各アクセスネットワークごとに，端末が最初にアクセスする SIPサーバ. 端末からの SIP メッセージを S-CSCF に転送する.

I-CSCF : Interrogating-Call Session Control Function ；CSCF 間の SIP メッセージを転送する SIPサーバ. 
三つのステップで行われる.

まず, S-CSCFに対して端末の登録処理が行われる. ユーザが動き回るごとに，着信のために IP アドレスを登 録する必要がある，そのため，携带電話網から WiMAX 網にハンドオーバする場合などにも，端末の登録処理は 必要となる。なお，不正なユーザの IMS の使用を防ぐた めに, ユーザの認証も登録時に併せて行われる.

端末の登録に当たっては，端末 $\Rightarrow \mathrm{P}-\mathrm{CSCF} \Rightarrow \mathrm{I}-\mathrm{CSCF}$ $\Rightarrow \mathrm{S}-\mathrm{CSCF}$ の順に，ユーザの認証情報が含まれる SIP REGISTER メッセージがルーチングされる．S-CSCF は， 「ユーザの認証情報」「ユーザの加入サービスが記述された サービスプロファイル (サービス情報)」「ユーザの位置情 報」などが保持されている HSS にアクセスし，ユーザの 認証を行ってユーザの位置情報を更新するとともに，サー ビスプロファイルを入手することで，登録が完了する.

ここで，サービスプロファイルには，SIP メッセージ をどのアプリケーションサーバに転送すべきかが記され ている iFC（initial Filter Criteria）が含まれている. IMS では, アプリケーションを S-CSCF ではなく, 別に配置 されたアプリケーションサーバで実施することを想定し ているため, 適切なアプリケーションサーバの選択を行 うために $\mathrm{iFC}$ が用いられる。

次に, ユーザがポータルページでアプリケーション 1 (会 議）の利用を要求すると, アプリケーションの利用登録処 理が行われる。具体的には，HSS 内の iFC を更新し，SIP INVITE メッセージをアプリケーション 1 (会議) に転送す るように設定する。また, HSS は更新された $\mathrm{FCC}$ を S-CSCF に通知し，S-CSCF は保存している $\mathrm{iFC}$ を更新する。

利用登録処理が完了した時点で，登録したアプリケー ションをユーザが利用できるようになり，当該アプリ ケーションに対してセッション確立処理を行うことで アプリケーションの利用が開始される，具体的には，ア プリケーション1 (会議) の SIP アドレスに対して SIP INVITE メッセージを送信するＳSIP INVITE メッセー ジは，ユーザのホームネットワークの S-CSCF に配送さ れ, iFC に基づきアプリケーション 1 のアプリケーション サーバに転送するか否かの判断がなされた後で，アプリ ケーションサーバのホームネットワークの S-CSCF を経 由して, アプリケーション 1 (会議) のアプリケーション サーバに配送される。なお，アプリケーション 2 (ゲー ム）のように, iFCに登録されていないアプリケーション
サーバへの転送は，S-CSCF において遮断される。

なお, 図 1 のような会議アプリケーションでは, 端末 とアプリケーションサーバ間で映像や音声のフォーマッ 卜の詳細を決定し，必要であれば QoS を用いるように ネットワークを制御するなどの処理が併せて行われる.

\section{IMS 上のアプリケーション}

本章では，IMS 上のアプリケーションとして，IMS 基 本アプリケーション, OSA（Open Service Access）[3] ア プリケーション, CAMEL (Customized Applications for Mobile network Enhanced Logic）[4] アプリケーションを 示すことで, IMS が具備する機能を明らかにする。 なお， 本章で示すアプリケーションは, 現時点で想定されてい るもののみである。サードパーティ事業者には閉ざされ ていたネットワーク内機能が利用可能となることで，今 後 IMS 上に多彩なアプリケーションの創出が期待されて いることに留意されたい。

\subsection{IMS 基本アプリケーション}

もともと IMS の基本仕様とアーキテクチャは，第 3 世代携帯電話の標準化団体である 3GPP (3rd Generation Partnership Project）が 2002 年に 3 GPP リリース 5 の一部 [5］として，IP ベースのマルチメデイアサービス提供基 盤として策定したものである。

3GPP では携帯電話に関係する標準を数多く策定して いるが，IMS の機能はアクセスネットワークが移動系 であるか固定系であるかということに依存しないため, 無線 LAN や光 IP 網などを含む多様なアクセスネット ワークに適用することができる. IMS で使用されるプロ トコルのほとんどは IETF で策定されたものを流用し， インターネット技術との親和性も高いこともあり, ITU, TISPAN（欧州電気通信標準化協会（ETSI）の NGN 標準 化プロジェクト), CableLabs (CATV 系の標準化機関) な どの様々な標準化団体で IMS を利用したサービス構築 が検討されてきた．複数の団体で標準化を進める場合に は，どうしても作業の重複やお互いの仕様間での矛盾が 生じる可能性があるため, 2007 年 4 月に共通に利用可能 な IMS を共通 IMS [6］として 3GPP で標準化すること になった [7]. 
図 2 に, 共通 IMS とアプリケーションやアクセスネッ トワークとの関係を示す.3GPP, TISPAN, OMA（Open Mobile Alliance）などの標準化団体で策定されたアプリ ケーションが共通 IMS の上に位置するとともに，3GPP， TISPAN，WiMAX フォーラムなどで策定されたアクセ スネットワークが共通 IMS を支える構造となっている $[5],[8] \sim[10]$.

ここでは，図 2 に挙げたアプリケーションのうち, 3GPP, TISPAN, OMA において IMS ネットワーク向け アプリケーションとして策定されたものを基本アプリ ケーションとして，以下で説明する。

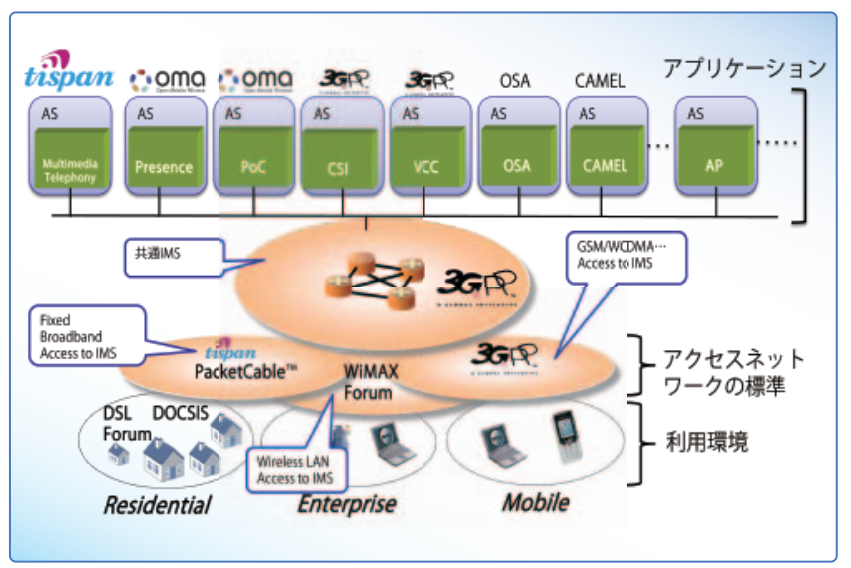

図 2 共通 IMS を中心とした NGN 関係標準化機関の位置付け とアプリケーション

\section{(1) Multimedia Telephony}

ユーザ間やユーザ・サーバ間を同時に複数接続し，音 声，ビデオ，チャット，画像などを送受信したり，ビデ オ共有などを行うためのサービスである [11]，[12]，通 常は双方向で利用されるＩIMS では，セッション確立に セッション記述プロトコル [13］を用いるため, 同時に多 様なメディア形式を扱うことが可能である。 セッション 記述プロトコルのネゴシエーション機能によって, 映像 コーデック，音声コーデック，画面サイズ，通信速度と いった端末が具備する能力に応じてマルチメディアコ ミュニケーションを行うことができる，また， QoS 確 保機能によって, 高品質なマルチメディアコミュニケー ションを実現できる。

\section{(2) プレゼンスサービス}

ユーザの状態を集約し，通知するためのサービスであ る [14].「会議中なので連絡しないで」「今ヒマ」などと いった自分の状態やスケジュールを，指定した相手に通 知することができる.
プレゼンスサービス自体は，現在のインターネット上 のサービスとしておなじみのものであるが，IMS にお いてプレゼンスサービスを担う PS (Presence Server) で はオン・オフラインといった通信状態の情報だけではな く, 所在地情報（住所や緯度経度など）, コンタクト情報 (名刺情報や URI など), 端末能力情報（映像コーデック や音声コーデックなど), 時間軸情報（イベント開始・終 了時間）など，多様なプレゼンス情報を HSS や XML 文 書管理サーバ（XDMS）[15］などから収集し，XML 形 式で提供する機能を有する.

したがって，PS はほかのサービスから参照されるこ とによって，更なる価值を生み出すことになる，例えば， 通信相手のプレゼンス状態に応じて通信手段を変更した り，位置に応じた情報を提供する位置情報サービスなど を実現することができる。

\section{(3) PoC : Push to talk over Cellular}

携帯電話を使ってグループ内でトランシーバのような 1 対多の片方向の音声通話を行うためのサービスである [16]，[17]．音声通話は IP で行われる.

PoC は，音声通話が可能なユーザを把握するために， XDMS のグループ情報収集機能と PS のプレゼンス情報 提供機能とを使用する．PoC は，プレゼンスサービスと 密接に関係しているため, プレゼンスサービスの付加価 值サービスとして提供されることもある。

\section{(4) CSI : combination of CS and IMS services}

既存の回線交換のネットワークと IMS サービスとを組 み合わせて実現するサービスである [18]。例えば，既存 の回線交換ネットワークで音声通話を提供しつつ, 高速 なアクセスネットワークを用いて画像やファイルを転送 したり，ビデオ共有を行うサーバを呼び出したりする.

CSI は，使用可能なアクセスネットワークと端末能力 の把握のために，HSS による端末の位置情報管理機能， XDMS の端末能力収集機能, SIP OPTIONS メッセージを 使った端末能力問合せ機能を使用する。 また，通話の途中 でビデオ共有サーバを追加するためには SIP INVITE メッ セージを使ったセッションの再設定機能を使用する.

\section{(5) VCC : Voice Call Continuity}

回線交換ネットワークと IMS ネットワークとの間で, 電話呼を継続して利用できるようにするサービスである [19]。例えば，既存の回線交換の電話サービスを，帰宅 時には宅内の Wi-Fi などを介した IMS 電話サービスに途 
切れることなく切り換え，呼・サービス制御レベルでの 移動性を提供する。

VCC は，上記の CSI と同様，使用可能なアクセス ネットワークと端末能力を把握するために，HSS による 端末の位置情報管理機能, XDMS の端末能力収集機能, SIP OPTIONS メッセージを使った端末能力問合せ機能を 使用する。

\subsection{OSA アプリケーション}

OSA アプリケーションは, Parlay Group で標準化が 進められている Parlay/OSA API (Application Program Interface）上に構築されたアプリケーションである。ネッ トワークから提供されるユーザ情報を利用したVPN や 会議アプリケーション，位置情報を利用したアプリケー ションなどが提供されている.

IMS 上で OSA アプリケーションを動作させるために は，ゲートウェイを介して Parlay/OSA API に接続するこ とになる. IMS は，このゲートウェイに対して，ユーザ 情報や端末情報などを提供する機能を有している。

なお，OSA アプリケーションの特徴は，使用するプ ロトコルやデータ利用の柔軟性にある。すなわち，プロ トコルやデータ形式は，ネットワーク側とアプリケー ション側とのネゴシエーションによって決定される.

\subsection{CAMEL アプリケーション}

CAMEL アプリケーションは，ETSIに設けられた SMG（Special Mobile Group）で検討が進められてきた インテリジェントネットワーク（IN）[20］上のアプリ ケーションである.

CAMEL アプリケーションの代表的なものとして, GSM (Global System for Mobile Communications) や UMTS (Universal Mobile Telecommunications System) 網で提供 される SMS (Short Message Service) や MMS (Multimedia Messaging Service）などが挙げられる。また，3.1 中の， CSI と VCC は CAMEL アプリケーションでもある.

IN 上に実装された CAMEL アプリケーションを IMS においても利用可能とすることは，通信事業者にとって IMS 導入に欠かせない要件であり, IMS 側からはゲート ウェイを介して CAMEL アプリケーションを利用するこ とになる.すなわち IMS は，このゲートウェイに対して， ユーザ情報や端末情報などを提供する機能を有している。

\section{SDP: サービス提供基盤}

IMS が具備するユーザ情報管理機能やネットワーク制 御機能などを使った多彩なアプリケーションの創出が期 待されているものの，IMS ではインタフェースが規定さ れているのみで，アプリケーション構築に資する機能ま では規定されていない，本章では，SDPが提供する機能 や構成例を示し, 多彩な IMS アプリケーションの創出に 向けて SDPが果たすべき役割を明らかにする.

\subsection{SDP の位置付け}

図 3 に，IMS，SDP，アプリケーションの関係を示す. SDP は, IMS とアプリケーションを仲介するものである が，とらえ方によって狭義の SDP と広義の SDP がある.

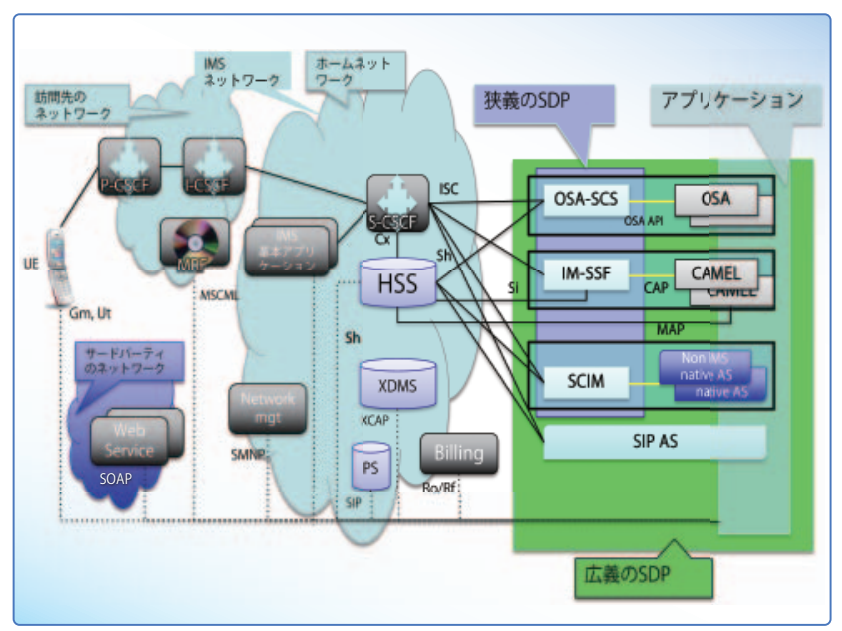

図 3 IMS, SDP, アプリケーションの関係

\section{（1）狭義の SDP}

狭義の SDP は, OSA アプリケーションや CAMEL ア プリケーションなどの既存のアプリケーションを IMS 上で動作させる「ゲートウェイ」機能を有し, OSA-SCS (Open Service Access-Service Capability Server), IM-SSF (IP Multimedia Service Swithing Function), SCIM (Service Creation Interaction Manager）から構成される.

\section{(a) OSA-SCS}

OSA-SCS は, 既存の OSA アプリケーションサーバ を IMS で実行するためのゲートウェイ機能を提供する. 具体的には, IMS への要求や IMS からのイベント通知 などを OSAAPI に変換する機能を有する $[21]$. 


\section{(b) IM-SSF}

IM-SSF は, GSM 網で広く展開されている CAMEL アプリケーションサーバを実装する既存サービス網と IMS とのゲートウェイ機能を提供する。具体的には，呼 状態と HSS から得られる加入者情報を CAP (CAMEL Application Part）インタフェースを使って CAMEL アプ リケーションに提供する機能を有する [22]，[23].

\section{(c) SCIM}

SCIM には，二つの機能が定義されている。一つは， イントラネットやインターネット上のウェブサービスの ようにインターネットでは使われているものの IMS には 対応していない非 IMS ネイティブアプリケーションサー バを IMS 上で動作させる変換サーバとしての機能であ る.もう一つは, サービスオーケストレーション機能で, アプリケーション間の連携を管理する機能である。これ については, 4.3 で説明する。

以上のように, OSA-SCS, IM-SSF, SCIM を用いる ことで, IMS に対応していない既存の OSA アプリケー ション, CAMEL アプリケーション， 非 IMS ネイティ ブアプリケーションを, IMS 上で動作させることが可能 となる。すなわち，狭義の SDP は，S-CSCF との間での IMS のセッション確立機能と, HSS との間でのユーザの サービスプロファイル管理機能とを抽象化したものを既 存アプリケーションに提供する機能を有する.

なお, OSCA-SCS, IM-SSF, SCIM の内部構成につ いては規定されておらず, 眓 3 に示すようにS-CSCF や HSS との間のインタフェースが定義されているのみ である。

\section{(2) 広義の SDP}

広義の SDP は，狭義の SDP の機能に加え，アプリ ケーション開発において共通して用いられる機能を具備 したものである. 3.で記した IMS 基本アプリケーション, OSA アプリケーション, CAMEL アプリケーション以 外のアプリケーションを提供したい場合には，新たにア プリケーションを構築しなければならない. 広義の SDP は，新たなアプリケーションの構築に資するサービス提 供基盤である.

一般に，アプリケーション構築を行う際には, Linux などのサーバ OS 上のアプリケーションサーバという名 のミドルウェアを用いて, Java や C などのプログラミン グ言語でアプリケーションプログラムを作成する。例
えば，インターネット上で広く用いられるウェブアプリ ケーションであれば, アプリケーションサーバに Tomcat を採用することで, Tomcat が提供する機能に関しては Tomcat に任せて，そのウェブアプリケーションを特色付 ける機能のみを実装することになる。

すなわち，アプリケーションサーバは，複数のアプリ ケーションで共通して用いられる機能を備えたものであ り，アプリケーションサーバを用いることでアプリケー ションの開発コストの低減が可能となる.

SDP も, アプリケーションサーバと同様に, IMS 上の 複数のアプリケーションで共通して用いられる機能を備 えている. IMS の特徵は, 呼制御機構, ユーザ情報管理 機構, 認証・課金・決済機能, XDMS, ウェブサービス などの各種サービス要素を用いて付加価值の高い魅力的 なアプリケーションを提供できることにある。そのため， SDP の場合には，IMS アプリケーション構築に当たって 必要となる各種サービス要素への API などが提供される.

具体的には，図 3 に示すように，呼制御機能を担う S-CSCFへの ISC インタフェース, ユーザ情報管理機能 を担う HSS の Sh インタフェース, 認証 ・課金・決 済機能を担うコンポーネントへの Ro/Rf インタフェース を使うための機能を提供する。また，ウェブサービスや XDMS との連携を四るために SOAP (Simple Object Access Protocol) や XCAP (XML Configuration Access Protocol) といったプロトコルを使うための機能なども提供する.

SDPを用いることで, アプリケーション開発者は, IMS のインタフェースの利用方法の詳細などを気にする ことなく，アプリケーションプログラムを構築すること が可能となる。また，通信事業者にとっては，SDPを提 供することでサードパーティ事業者の参画を容易にし， 多様なアプリケーションの創出を促すことで，ネット ワークの価值を高めることができる。

\subsection{SDP を用いたアプリケーション例}

本節では，SDP 上で構築されるアプリケーション例を 示すことで, SDP を用いて多彩なアプリケーション構築 が可能となることを示す。

図 4 に,SDP を用いた「ディジタルサイネージ向けクー ポン発行システム」のシナリオを示す。本シナリオでは, GPS 携帯電話をユーザが保持しており，ネットワーク 側がユーザの位置情報を把握している環境を想定してい 


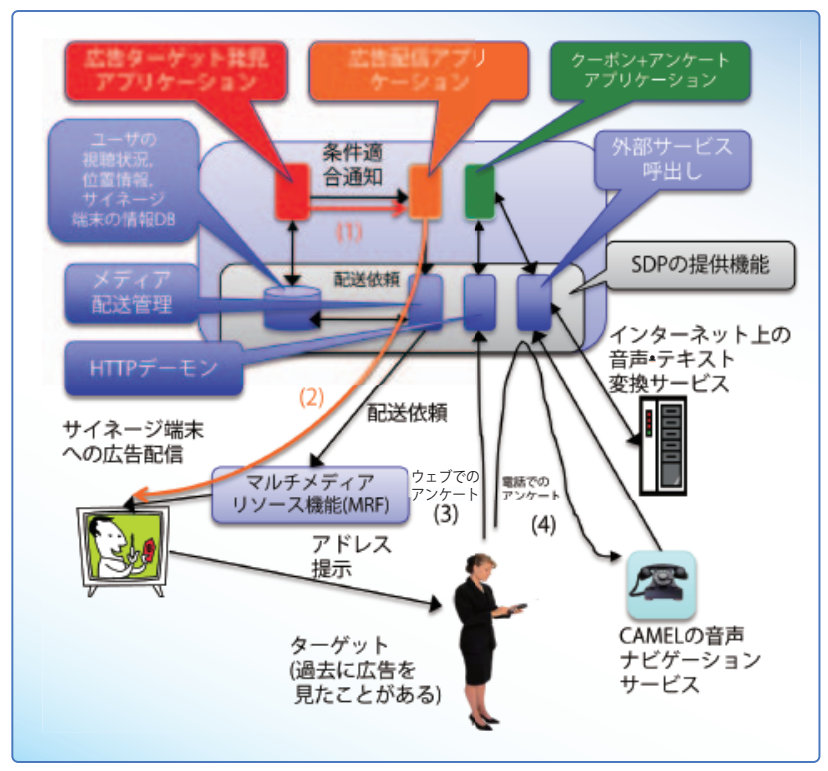

図 4 ディジタルサイネージを用いたクーポン発行システム

る。また，動画配信サービスでのユーザ視聴履歴もネッ トワーク側が把握している環境を想定している.

まず，「広告ターゲット発見アプリケーション」は, ユー ザの視聴状況・ユーザの位置情報・サイネージ端末の 位置情報が記録されているデータベースを用いて，商 品 $\mathrm{A}$ の宣伝を動画配信サービスで以前視聴した人が, サイネージ端末の近くに位置することを検出する（眓 4 (1))。すると，「広告ターゲット発見アプリケーション」 は，当該条件を満たしたユーザ名を「広告配信アプリケー ション」に対して通知し, ユーザの近くに存在するサイ ネージ端末に向けての広告配信を行うように制御する.

「広告配信アプリケーション」は, メディア配送管理 機能とマルチメディアリソース機能（MRF：Multimedia Resource Function）を介して，データベースに保持されて いるサイネージ端末の解像度情報や回線情報に基ついて, 適した映像フォーマットで広告を配信する（図 4 (2)).

広告にはウェブの URL とアンケートサービスの自動 応答電話番号とが表示されており，ユーザはいずれかの 方法でアンケートに答えると「クーポン+アンケートア プリケーション」がクーポンをユーザに発行する。ここ で，ユーザがウェブブラウザ上でアンケートに答える場 合には, HTTP デーモンを介して「クーポン+アンケー トアプリケーション」に入力結果が送信され, データベー スに入力結果が保持される（図 4(3)). これに対して, 自動応答電話番号に対してユーザがアンケートに答える 場合には, CAMEL アプリケーションで構築された音声
ナビゲーションサービスを用いてアンケート入力が行わ れ，「クーポン+アンケートアプリケーション」にアン ケート入力結果が送信された後, データベースに入力結 果が保持される（図４（4））。なお，ユーザ氏名など音声 入力が必要なアンケート入力項目については，「クーポン +アンケートアプリケーション」が外部サービス呼出し 機能を介して音声・テキスト変換サービスを呼び出し, 音声入力をテキストに変換する。 このような仕組みを用 いることで, 自動応答電話番号に対してアンケートに答 える場合であっても, ウェブブラウザ上でのアンケー 卜入力と同様に，テキスト処理アプリケーションとして 「クーポン+アンケートアプリケーション」を構築するこ とができる。

\subsection{SDP の構成例}

SDP は, アプリケーション開発において共通して用い られる機能を具備したものである。本節では, 4.2 で示 したアプリケーション例での SDP の利用を参照しなが ら, SDP が備える機能を示す。なお, SDP のイメージや 機能は，通信事業者やベンダによって異なっているのが 現状であり，図 5 に示した SDP の構成は一例であるこ とに留意されたい。

SDP が提供する機能は, 大きく「ネットワーク接続の 抽象化」「ユーザ情報の活用」「サービスオーケストレー ション」「ロギングとアクセス制御」「アプリケーション サーバの運用支援」の五つに分けられる。

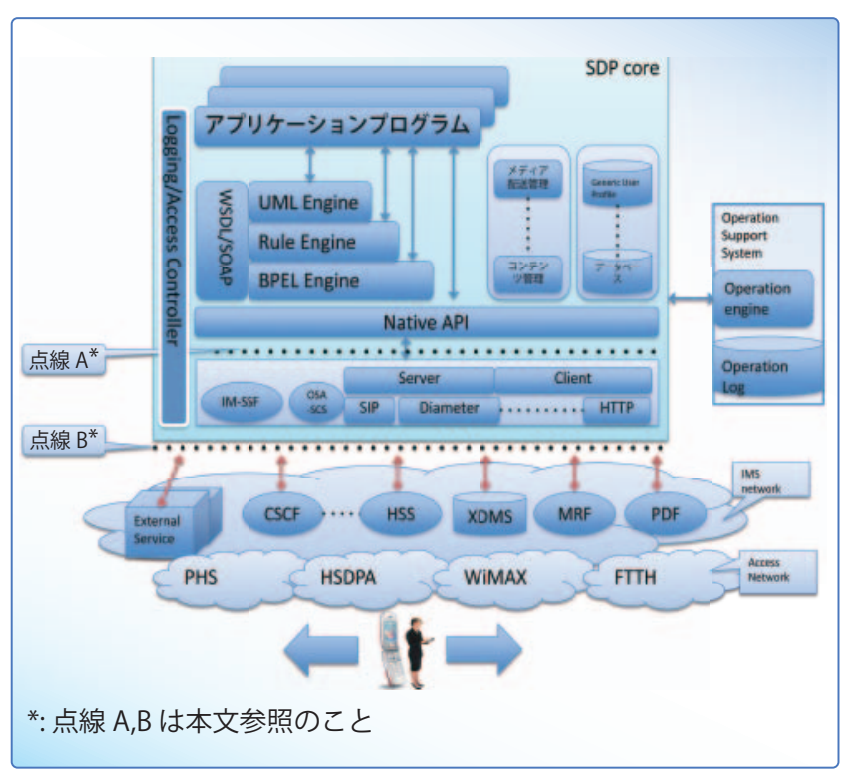

図 5 SDP の構成例 


\section{（1）ネットワーク接続の抽象化}

ネットワーク接続の抽象化は, IMS アプリケーション 構築に当たって必要となる呼制御機能，ユーザ情報管理 機能, 認証・課金・決済機能など SDP 内外の各種サー ビス要素への接続機能の詳細な実装を隠す手段である. 図 5 に示寸構成例では, 点線 A や点線 B で抽象化がな されている。

4.2 で示したアプリケーション例では，メディア配送管 理（図 5 の点線 B の上部）と HTTP デーモン（図 5 の点 線 A の上部：HTTP と Server）が，ネットワーク接続の 抽象化機能であるととらえることができる、メディア配 送管理機能を用いることで, サイネージ端末の解像度・ 位置・回線情報（(HSDPA：High Speed Downlink Packet Access）で接続されているのか，PHS で接続されている のかなど）を考慮することなく，アプリケーションをプ ログラムすることができる、メディア配送管理機能が, サイネージ端末情報が保持されているデータベースにア クセスして, サイネージ端末の解像度・位置・回線速度 を把握し，MRFを介して解像度や回線速度に合わせてト ランスコードを行ってユーザの身近のサイネージ端末に 配信するためである。すなわち，アプリケーションプロ グラムは，単に配信すべき広告映像データのみを渡すだ けでよい.

また，HTTP デーモンは，ネットワークからの HTTP メッセージを点線 B の上部に位置するアプリケーション プログラム (クーポン+アンケートアプリケーション)に 中継する機能を有している。

\section{(2) ユーザ情報の活用}

IMS では，ユーザの位置情報，プレゼンス情報，課金 情報，デバイス能力情報，連絡先リスト（電話帳）など多 様なユーザ情報を活用することができる.

これらの情報は，HSS，課金サーバ，XDMS などに 分散して保存されているが，図 5 の GUP (Generic User Profile）[24］は，これらの分散して保存されている情報 を収集し，一つのデータベースに保存する仕組みである。

GUP を用いることで，アプリケーションプログラムは GUPのみに問合せを行うだけでよい.4.2で示したアプ リケーション例では，ユーザの視聴情報・ユーザの位置 情報・サイネージ端末情報が記録されているデータベー スを利用して広告配信を行うが，このデータベースが GUP となる。

\section{(3) サービスオーケストレーション}

IMS においては, アプリケーション間の連携（サービ スオーケストレーション) を管理する機能である SCIM が枠組みとして定義されている [25]。例えば，ゲーム本 体をゲームサーバ上で動作させ，ゲームに付随する音楽 デー夕を音楽サーバからストリーム再生するゲームアプ リケーションを構築する場合には，ゲームサーバと音楽 サーバとを連携させなければならない。このようなアプ リケーション間の連携をサービスオーケストレーション と呼ぶ. 複数のアプリケーションを連携させることで, 多彩なアプリケーション構築を可能とすることがサービ スオーケストレーションの目的である。

4.2 で示したアプリケーション例では, CAMEL アプ リケーションで構築された音声ナビゲーションサービス と, 音声・テキスト変換サービスとが連携して, 音声入 カのテキスト変換を行う自動応答アンケートサービスを 提供している.

図 5 の BPEL エンジンは, サービス連携シナリオ (サービスオーケストレーションに扮いてサービス連携 の順序を記したもの）を記述するプログラミング言語 (BPEL: Business Process Execution Language) [26] を解 釈し，実行するエンジンである，BPEL を用いることで， 多数のアプリケーション間の複雑な連携を設計すること が可能となる。

\section{（4）ロギング機能とアクセス制御機能}

SDP は，ロギング機能とアクセス制御機能を提供す る、ロギング機能とアクセス制御機能は，すべてのアプ リケーションにおいて必要となる機能であるため, SDP で一元管理することで管理コストの低減を図ることが目 的である. 4.2 で示したアプリケーション例では，「クー ポン+アンケートアプリケーション」や外部の音声・テ キスト変換サービスを使用したときに，ロギング機能や アクセス制御機能が用いられる。

\section{（5）アプリケーションプログラムの運用支援}

SDP は，アプリケーションプログラムを IMS で安定 的に動作させるための機能をも提供している．例えば, 4.2 で示したアプリケーション例では, SDPのメディア 配送管理機能を介して MRF に広告配信を行わせている. MRF は, メデイアを処理・加工し, 送信を行う機能であ り, IMS では網内各所に配置されている. SDP が，メディ ア処理・加工 · 送信といった処理の重い機能を分散配置 
されている $\mathrm{MRF}$ を適切に制御することで，ネットワー クの負荷分散を図り，アプリケーションプログラムの安 定運用を実現できる。

このほかにも，大規模システムである SDP の監視・ 管理を行うオペレーションサポートシステム（OSS： Operation Support System）などの機能も提供されている.

\section{4 SDP の研究動向}

SDP は，IMS が具備する機能とアプリケーションとを 仲介するオープンなアプリケーション開発環境であり, SDP を用いることでアプリケーション開発速度の向上や コスト低減を図ることができる，しかしながら，複数の アプリケーションを連携させて多彩なアプリケーション 構築を行うサービスオーケストレーションなどにおいて は，アプリケーション開発コストが低いとは言い難い。 そのため, アプリケーション開発の生産性を更に高める ために以下のような研究開発が進められている.

\section{(1) ルールエンジンの使用}

4.3 (3) で述べたサービス連携シナリオを記述する BPEL では，if-then 文が用いられる，そのため，条件数 が増大すると，開発コス卜，検証時間，バグの増大を招 いてしまう。このような観点から, Reteアルゴリズム ［27］を採用したルールエンジンとして Drools を用いる 方法 [28] などの検討が行われている.

\section{(2) サービス記述法の改善}

サービス連携シナリオの記述では, 個々のサービス要 素を呼び出す手続きを詳細に記述しなければならないた め，BPELを用いたとしても記述の困難性が指摘されて いる [29]。このような観点から, 統一モデル言語 (UML: Unified Modeling Language）でサービスを記述して BPEL に変換する方法 [30] や，Eclipse の統合環境を利用する 方法 [31] などが提案されている.

\section{(3) サービス連携の自動化}

サービス連携シナリオを記述する BPEL では，扱う データやサービスの詳細に精通している必要がある。こ のような観点から，データやサービスを Semantic Markup for Web Services（OWL-S）を用いて記述し，サービスに 関する一般的な知識を用いて推論することで，サービス 連携の自動化を図る方法 [32］，[33］などの検討が行わ れている.

\section{5.むす び}

IMS が具備するユーザ情報管理機能やネットワーク制 御機能などを使うことで, 多彩なアプリケーションの創 出が期待されている。しかしながら, IMS はインタフェー スが規定されているのみで，サービス構築に資する機能 まで規定されていない. SDP は, IMS 上でサービス構築 に役立つ様々な機能を提供するオープンなサービス提供 基盤であり，SDP を用いることでアプリケーション開発 速度の向上やコスト低減を図ることができる.

IMS の特徵は，今まで通信事業者内に閉じた門外不 出のユーザ情報管理機能やネットワーク管理機能などを サードパーティ事業者に公開することで, 多種多様なプ レーヤにアプリケーション開発をゆだねる点にある。今 後, 数多くのプレーヤが参入し, SDP 上で多種多様なサー ビスが花開くことを期待したい.

\section{[用語解説］}

・アプリケーションサーバ (AS : Application Server) : サービス の実行主体となる。

・インテリジェントネットワーク (IN ：Intelligent Network)：高 機能で柔軟かつカスタマイズ可能な電話サービスを提供する ネットワーク.

・ウェブサービス：HTTP などのウェブ技術を利用したメッ セージの送受信によって提供されるサービスの総称.

・セッション記述プロトコル (SDP : Session Description Protocol) : 本論文では, Service Delivery Platform との混用を避けるた めに，「セッション記述プロトコル」と記述した. IETF RFC 4566 で定義. セッション告知，セッションの招待などの形式 を持つマルチメディアセッションを開始する目的で，マルチ メディアセッションを記述するためのプロトコル.

・ストラタム（Stratum）：NGN のアーキテクチャにおいては, OSI の 7 階層モデルのように, 整然とした階層化ができないた め, 混同を避けるためにレイヤの代わりに本用語が使われる.

-3GPP (3rd Generation Partnership Project)：第 3 世代携帯電話 の標準化団体. http://www.3gpp.org/

- Cable Labs (Cable Television Laboratories) : CATV 機器の R\&D 及び認定のための非営利組織.

- DOCSIS (Data Over Cable Service Interface Specification) Cable Labs が認定している. ケーブルテレビネットワークを 用いたデータ通信のためのプロトコルや機器設定の制御イン タフェース規定.

- Drools：RedHat 社によるJava で実装されたオープンソース のルールエンジン. http://jboss.org/drools/

- DSL（Domain Specific Language）：特定のタスク向けに設計 されたプログラミング言語. 生産性と品質を向上させるもの としてソフトウェア工学の分野で注目されている. 
・Eclipse：プログラミングやデバッグといったソフトウェア開 発作業を効率化するオープンソースの IDE（統合開発環境）の 一つ. Java 開発者を中心に広く普及している.

- GSM (Global System for Mobile Communications) : ディジタ 儿携帯電話で使われている無線通信方式で，事実上の世界標 準. ヨーロッパやアジアを中心に 100 か国以上で利用されて いる.

・HSS (Home Subscriber Server) : 加入者のサービスプロファイ ル，認証情報，位置情報の管理を行う.

- HSDPA (High Speed Downlink Packet Access) : $3.5 \mathrm{G}$ ともい われる高速携帯電話向け通信サービス.

・IETF (Internet Engineering Task Force)：インターネットで利 用される技術を標準化する組織。ここで策定された技術仕様 は IETF RFC として公表される.

•iFC（initial Filter Criteria）: SIP メッセージをどのアプリケー ションサーバに転送すべきかが記された XML 形式の制御文. -IPTV (Internet Protocol Television)：IP 放送による映像配信 サービス.

- MMS (Multimedia Messaging Service) : 3GPP と OMAによっ て標準化されている携帯電話用のメッセージングサービス.

・OMA (Open Mobile Alliance)：モバイルにおけるアプリケー ションの技術標準化団体. http://www.openmobilealliance.org/

-OWL-S (Semantic Markup for Web Services)：セマンティック ウェブ上で構築された意味体系とウェブサービスとを結び付 け，ウェブサービスの合成を行うためのメタデータ.

・PacketCable：ケーブルテレビのネットワーク上で IP ベース のブロードバンドサービスを実現させる仕様.

http://www.packetcable.com/

・Parlay Group : 通信機器ベンダやソフトウェアベンダ, 通信 事業者によって設立されたテレコムネットワーク向けの API を定める技術団体. 成果としては, Parlay/OSA API, Parlay X, JAIN がある.

-PoC (Push-To-Talk over Cellular)：OMA によって定められ たモバイル向けの 1 対 1 , あるいはグループでトランシーバ のように一斉に音声やその他メディアを発信するサービス。 NTT ドコモのプッシュトーク, KDDI の Hello Messenger, ソ フトバンクモバイルの S! 一斉トークなどが該当する.

・PSTN/ISDN エミュレーション：ユーザにPSTN/ISDN と同 等なサービスとインタフェースを IP のインフラを用いて提供 するサービスのこと. 電話交換機を置き換え， ユーザの使用 する電話機はそのままで使用できる.

・QoS（Quality of Service）：データやサービスの内容によって ネットワークでのデータ転送の扱いに差をつけること. 優先 制御と帯域制御に分けられる。

•SMG (Special Mobile Group)：ETSI のプロジェクトで, GSM やUMTS などの移動体通信の規格制定を行っていた．現在は 3GPP 内の TSG GERAN に移管されている.

- SOAP (Simple Object Access Protocol)：RPC のために使われ るXML を利用したメッセージプロトコル，通信プロトコル としてはHTTPがよく使われる。

-SIP (Session Initiation Protocol)：セッションの確立, 変更, 切断などを行うためのプロトコル。

・SIP INVITE：ユーザを招待するための SIP メソッド.

-SIP REGISTER：SIP サーバに対し登録要求を行うための SIP メソッド。受信すると, 通常 SIP URI と IP アドレスとの対が
サーバのデータベースに登録される。

- SNMP (Simple Network Management Protocol)：ネットワーク 機器を監視，制御するためのプロトコル。

- TISPAN (Telecoms \& Internet converged Services \& Protocols for Advanced Networks)：ETSI のプロジェクトでNGN の標 準化団体の一つ.

-UE (User Equipment）：ユーザ端末のこと.

・UML (Unified Modeling Language) : 統一モデル言語. オブ ジェクト指向のソフトウェア開発における，プログラム設計 図の統一表記法.

- UMTS (Universal Mobile Telecommunications System) : GSM の発展形となる $3 \mathrm{G}$ 携帯電話システム。

・WSDL（Web Services Description Language）：ウェブサービス で提供されるデータ型や操作を定義するXML ベースの言語.

\section{文 献}

[1] ITU-T, "General overview of NGN," Recommendation Y. 2001, International Telecommunication Union, Dec.2004.

[2] ITU-T, "IMS for Next Generation Networks," Recommendation Y. 2021, International Telecommunication Union, Sept. 2006.

[3] Open Service Access Application Programming Interface; Part 1: Overview, TS29.198-01, 3rd Generation Partnership Project, March 2007. http://www.3gpp.org/ftp/Specs/html-info/29198-01.htm

[4] Customized Applications for Mobile network Enhanced Logic Phase X; Stage 2, TS23.078, 3rd Generation Partnership Project, Sept. 2007. http://www.3gpp.org/ftp/Specs/html-info/23078.htm

[5] Service requirements for the Internet Protocol multimedia core network subsystem; Stage 1, TS 22.228, 3rd Generation Partnership Project, Dec. 2007. http://www.3gpp.org/ftp/ Specs/html-info/22228.htm

[6] Technical Specifications and Technical Reports relating to the Common IP Multimedia Subsystem, TS 21.202, 3rd Generation Partnership Proejct, Dec. 2009. http://www.3gpp.org/ftp/Specs/html-info/21202.htm

[7] Draft summary minutes, decisions and actions, 3GPP Organizational Partners Meeting\#17, pp.1-12, April 2007. http://www.3gpp.org/ftp/tsg sa/TSG SA/TSGS 36/ Docs/SP-070414.zip

[8] European Telecommunications Standards Institute, “ETSI TS 182006 V1.1.1, "Telecommunications and Internet converged Services and Protocols for Advanced Networking; IP Multimedia Subsystem; Stage 2" description," March 2006.

[9] Open Mobile Alliance, "Utilization of IMS capabilities Requirements," Aug. 2005.

[10] WiMAX Forum, "T33-001-R015v01, "Detailed Protocols and Procedures, IP Multimedia Subsystem Interworking,", Nov. 2009.

[11] IP Multimedia Core Network Subsystem Multimedia Telephony Service and supplementary services; Stage 1, TS 
22.173, 3rd Generation Partnership Project, Dec. 2007. http://www.3gpp.org/ftp/Specs/html-info/22173.htm

[12] IP Multimedia Subsystem; Multimedia telephony; Media handling and interaction, TS 26.114, 3rd Generation Partnership Project, Jan. 2008.

http://www.3gpp.org/ftp/Specs/html-info/26114.htm

[13] M. Handley, V. Jacobson, and C. Perkins, "SDP: Session Description Protocol," RFC 4566 (Proposed Standard), July 2006. http://www.ietf.org/rfc/rfc4566.txt

[14] Open Mobile Alliance, "Presence SIMPLE Specification," June 2008.

[15] Open Mobile Alliance, "XML Document Management (XDM) Specification," June 2008.

[16] Open Mobile Alliance, "Push to talk over CellularArchitecture," Sept. 2009.

[17] 3GPP enablers for Open Mobile Alliance Push-to-talk over Cellular services; Stage 2, TR 23.979, 3rd Generation Partnership Project, June 2007. http://www.3gpp.org/ftp/Specs/html-info/23979.htm

[18] Combining Circuit Switched and IP Multimedia Subsystem services; Stage 2, TS 23.279, 3rd Generation Partnership Project, Sept. 2007.

http://www.3gpp.org/ftp/Specs/html-info/23279.htm

[19] Voice Call Continuity between Circuit Switched and IP Multimedia Subsystem; Stage 2, TS 23.206, 3rd Generation Partnership Project, Dec. 2007.

http://www.3gpp.org/ftp/Specs/html-info/23206.htm

[20] ITU-T, "Principles of intelligent network architecture," Recommendation I.312/Q.1201, International Telecommunication Union, Dec. 1993.

[21] Open Service Access; Stage 2, TS 23.198, 3rd Generation Partnership Project, Dec. 2007. http://www.3gpp.org/ftp/Specs/html-info/23198.htm

[22] Customised Applications for Mobile network Enhanced Logic Phase 4; Stage 2; IM CN interworking, TS 23.278, 3rd Generation Partnership Project, March 2006. http://www.3gpp.org/ftp/Specs/html-info/23278.htm

[23] Customized Applications for Mobile network Enhanced Logic; CAMEL Application Part specification for IP Multimedia Subsystems, TS 29.278, 3rd Generation Partnership Project, Dec. 2005.

http://www.3gpp.org/ftp/Specs/html-info/29278.htm

[24] Service requirements for 3GPP Generic User Profile; Stage 1, TS 22.240,3rd Generation Partnership Project, Dec. 2004. http://www.3gpp.org/ftp/Specs/html-info/22240.htm

[25] Network architecture, TS 23.002, 3rd Generation Partnership Project, Dec. 2007.

http://www.3gpp.org/ftp/Specs/html-info/23002.htm

[26] T. Andrews, F. Curbera, H. Dholakia, Y. Goland, J. Klein, F. Leymann, K. Liu, D. Roller, D. Smith, S.Thatte, I. Trickovic, and S. Weerawarana "Business Process Execution Language for Web Services, version 1.1, May 2003.

[27] C. Forgy, "Rete: A fast algorithm for the many pattern/many object pattern match problem," Artificial Intelligence, vol.1, pp.17-37, Sept. 1982.

[28] N. Banerjee, K. Dasgupta, L. Longmore, S. Mukherjea, L.N. Ren, and J.J. Wen, "Service control layer: Enabling rulebased control and enrichment in next-generation telecom service delivery," ACM/I-FIP/USENIX Middleware'08 Conference, pp.1-6, Dec. 2008.

[29] M. Ingmarsson, H. Eriksson, and N. Hallberg, "Exploring Development of Service-Oriented C2 Systems for Emergency Response," May 2009.

[30] P. Mayer, A. Schroeder, and N. Koch, "Mdd4soa:Modeldriven service orchestration," 2008 IEEE Enterprise Distributed Object Computing Conference, pp. 203-212, Sept. 2008.

[31] The Eclipse BPEL Team, "The Eclipse BPEL Project," 2008. http://www.eclipse.org/bpel/

[32] J. P. Almeida, A. Baravaglio, M. Belaunde, P. Falcarin, and E. Kovacs, "Service creation in the SPICE service platform," 17th Wireless World Research Forum Meeting (WWRF 17), pp.1-7, Nov. 2006.

[33] Y. Araki, M. Sweeney, and H. Morikawa, "Flexible service composition architecture for NGN/IMS + Sensor/Actuator network," Int. Symp. Ubiquitous Computing Systems (UCS 2007), pp.21-22, Nov. 2007.

(平成 21 年 11 月 5 日受付, 平成 22 年 2 月 9 日再受付)

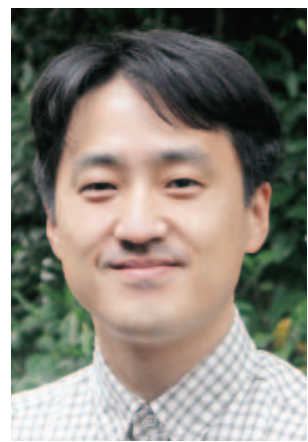

荒木靖宏 (正員)

平 9 東北大・エ・電子卒. 平 11 奈良 先端大学院大情報システム学専攻修士 課程了. 平 22 東大大学院基盤情報学 専攻博士了. 平 $13 \sim 22$ 日本ヒュー レット・パッカード研究所研究員. 現 在，(株）ディー・エヌ・エー・モバ イルネットワーク及びインターネット のサービスアーキテクチャの研究に従 事. IEEE, 日本データベース学会各会員.

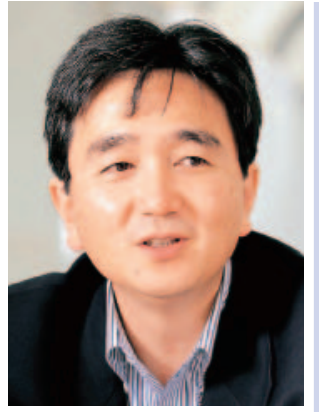

森川博之(正員: フェロー)

昭 62 東大・エ・電子卒. 平 4 同大学 大学院博士課程了. 現在, 同大学先 端科学技術研究センター教授. 工博. 平 9〜 10 コロンビア大客員研究員.

平 $14 \sim 18$ 独立行政法人情報通信研 究機構モバイルネットワークグルー プリーダ兼務. ユビキタスネットワー ク，無線ネットワーク，モバイルコ ンピューティング, フォトニックイ ンターネットなどの研究に従事. 本会論文賞（3 回），情報 処理学会論文賞，情報通信功績賞，ドコモモバイルサイエン ス賞など受賞. 平 $18 \sim 19$ 本会編集理事. 平 $20 \sim 22$ 本会 情報ネットワーク研究專門委員会委員長，通信ソサイエティ 英文論文誌編集長. IEEE，ACM，ISOC，情報処理学会，映 像情報メディア学会各会員. 